\title{
The Influence of the UN Watercourses Convention on the Development of the Nile River Basin Cooperative Framework Agreement (CFA)
}

Abiy Chelkeba*

\begin{abstract}
The 1997 UN Watercourses Convention has influenced the development of many bilateral and multilateral international water agreements. There is ongoing debate on the extent to which the Watercourses Convention has influenced the Nile River Basin Cooperative Framework Agreement (CFA). In this article, the author examines the interface between Watercourses Convention and CFA on some of the most contentious issues therein. It is argued that the Watercourses Convention has (in spite of various criticisms) greatly influenced the development of CFA in terms of the substantive and procedural contents of the agreement. The influence of the Watercourses Convention is more visible in shaping some of the major substantive principles such as the general obligation to cooperate, the principle of equitable and reasonable utilization, and the duty not to cause significant harm. The Watercourses Convention has also influenced the CFA's procedural rules such as the duty to exchange information, settlement of disputes and institutionalization of cooperation. In the era of increasing water security tension among the Nile River riparian states, the Watercourses Convention is set to dominate emerging new developments toward regulating the utilization, conservation, and management of the Nile River.
\end{abstract}

\section{Key terms}

Watercourses Convention · CFA · Nile · Impact · International Water Law

DOI http://dx.doi.org/10.4314/mlr.v12i1.6

Received: 5 February 2018

Accepted: 30 September 2018

This article is licensed under a Creative Commons Attribution-NonCommercialNoDerivs (CC BY-NC-ND)

\footnotetext{
* Abiy Chelkeba LL.B (MU), M.A (MU), LL.M (AAU); Assistant Professor of Law; and Amsterdam-Mekele University LL.M Joint programs project coordinator at School of Law, College of Law and Governance, Mekele University. I would like to thank the anonymous reviewers for their constructive comments. Email: chewabiy@gmail.com
} Frequently used acronym:

CFA Nile River Basin Cooperative Framework Agreement 


\section{Introduction}

On 21 May 1997, the General Assembly of the United Nations adopted the Convention on the Law of the Non-Navigational Uses of International Watercourses (Watercourses Convention) which it entered into force on 17 August 2014. ${ }^{1}$ The adoption of the Watercourses Convention resulted from to a two-decade process the General Assembly had initiated. ${ }^{2}$ On 8 December 1970, the General Assembly adopted resolution 2666 (XXV), entitled 'Progressive Development and Codification of the Rules of International Law Relating to International Watercourses'. ${ }^{3}$ In the same resolution, the General Assembly recommended that the International Law Commission 'take up the study of the law of the non-navigational uses of international watercourses with a view to its progressive development and codification'.

The Watercourses Convention is considered as one of the leading legal instruments in relation to non-navigational uses of international watercourses. The Watercourses convention has the advantage of being broad in concept and encompassing all aspects associated with non-navigational water use. The Watercourses Convention is basic framework convention that aims to regulate the different aspects of water use, water management, protection and conservation of transboundary watercourses, and 'promote optimal and sustainable utilization thereof for present and future generations'. As a framework convention, it lays down the fundamental substantive and procedural rules of the regulation of international watercourses and leaves the details for the riparian states so that they can draw their water agreements in the context of their respective river basins in question and if possible, harmonize it with Watercourses Convention. ${ }^{6}$

\footnotetext{
${ }^{1}$ The Convention was adopted on 21 May 1997 by G.A. Resolution 511229 with 106 affirmative votes, 26 abstentions and three negative votes, i.e. Burundi, China and Turkey. See United Nations (1997a) General Assembly Official Records, $99^{\text {th }}$ Plenary Meeting (A/51/PV.99), 21 May 1997 p. 7- 8. For a full text see: www.un.org/ga/documents/gares51/ga51-229.htm

${ }^{2}$ Stephen C. McCaffrey, Convention on the Law of the Non-Navigational Uses of International Watercourses, United Nations Audiovisual library of international law available at www.un.org/law/avI, p.1.

${ }^{3}$ Ibid.

${ }^{4}$ Ibid.

5 See the preamble of the Watercourse Convention, para 4. See also Salman M.A. Salman (2015), Entry into force of the UN Watercourses Convention: Why should it matter?, International Journal of Water Resources Development, 31:1, 4-16, , p.7. DOI: 10.1080/07900627.2014.952072

${ }^{6}$ Id., p. 8.
} 
The most robust and elaborated contents of the Watercourses Convention have (arguably) exerted impact on the negotiations and development of transboundary water agreements and cooperation in different basins. ${ }^{7}$ The impact of the Watercourses Convention is more visible with regard to the conclusion of an international water framework agreement in the context of the Nile river basin. In 2010, a number of Nile river riparian states concluded Nile River Basin Cooperative Framework Agreement (CFA) that was meant to replace the previous non-inclusive Nile water agreements. ${ }^{8}$ The CFA is a milestone agreement in terms of bringing many riparian states on board and has incorporated many of the recent international water law principles. These contemporary international water principles have been influenced by the Watercourses Convention and it is important to examine the extent of the influence of the Watercourses Convention on the CFA. This article seeks to examine the influence of the Watercourses Convention into the substantive and procedural rules of the CFA.

The first section discusses the various non-inclusive bilateral and multilateral water treaties that attempt to regulate the Nile River basin. Section 2 is an overview of the Watercourses Convention and the CFA. The third section examines the interface between the Watercourses Convention and the CFA and tries to indicate areas of influence of the substantive and procedural principles of the Watercourses Convention on the CFA.

\footnotetext{
${ }^{7}$ Around the time the ILC was in the last phase of preparing the 1994 draft articles, the number of water agreements negotiated and adopted was unusually high; two regional and a number of basin-level instruments were negotiated, including, at the regional level, the UNECE (1992) Convention on the Protection and Use of Transboundary Watercourses and International Lakes and the (SADC, 1995), Protocol on Shared Watercourse Systems in the Southern African Development Community; and, at the basin level, the Treaty on the Development and Utilization of Water Resources of the Komati River Basin (Kingdom of Swaziland and Republic of South Africa, 1992), the Convention on Cooperation for the Protection and Sustainable Use of the Danube River (ICPDR, 1994), and the Agreement on the Cooperation for the Sustainable Development of the Mekong River Basin (MRC, 1995), among others. See Christina Leb (2013): The UN Watercourses Convention: the éminence grise behind cooperation on transboundary water resources, Water International, 38:2, 146-155. p.152-153.

${ }^{8}$ The Nile River Basin Cooperative Framework Agreement (CFA) was signed by six of the riparian states, namely Ethiopia, Rwanda, Tanzania, Uganda, Kenya, and Burundi, and has been ratified only by three, i.e., Ethiopia, Rwanda and Tanzania. The text of the CFA is available at Nile Basin Initiative, "Agreement on the Nile River Basin Cooperative Framework opened for signature", available at:

http://www.nilebasin.org/index.php?option=com.
} 


\section{The Nile River Basin and Non-inclusive Agreements}

The Nile is the longest river in the world. There are eleven Nile River riparian states including South Sudan. The total population of the Nile Basin countries is estimated at 400 million $^{9}$ and 10 percent of the continent's land falls within the catchment area of the Nile River basin. ${ }^{10}$ The Nile has two major sources: the Blue and White Nile; both form the East African part of the Great Rift Valley. The Blue Nile originates in the Ethiopian highlands and constitutes about $86 \%$ of the annual flow of the Nile River. ${ }^{11}$ The White Nile has its main sources in Lake Victoria, which is shared by Tanzania, Uganda, and Kenya. ${ }^{12}$ The White and Blue Nile flow north and meet around Khartoum, Sudan, creating the Nile, which eventually flows into Egypt and on into the Mediterranean Sea. ${ }^{13}$ At 84 billion cubic meters, the Nile's average annual runoff is 'modest in comparison to the other major river systems in Africa, while the demand for its water is much higher'. ${ }^{14}$

A number of treaties on the Nile River were concluded during the last two centuries, and all of them are either less comprehensive or non-inclusive agreements. The "Treaty between Ethiopia and the United Kingdom, Relative to the Frontiers between the Anglo-Egyptian Sudan, Ethiopia, and Eritrea", was concluded in 1902 in Addis Ababa. ${ }^{15}$ The 1902 Agreement stipulates that the Ethiopian King will not 'construct, or allow to be constructed, any work across

\footnotetext{
${ }^{9}$ Ahmed Ibrahim and Alaa El-Nahry (2017), Population Growth and Impacts of Nile Water Deficiency on Egypt using Gis and other techniques, Egypt. Available at: https://www.researchgate.net/publication/305034095 (accessed 05 September , 2018), p.1.

${ }^{10}$ Peter Kagwanja (2007), 'Calming the Waters: The East African Community and Conflict over the Nile Resources', Journal of Eastern African Studies, 1:3, 321-337, p.323. DOI: $10.1080 / 17531050701625565$

${ }^{11}$ Tesfaye Tafesse (2001), 'The Nile Question: Hydropolitics, Legal Wrangling, Modus Vivendi, and Perspectives'. Lit., Münster, p. 24.

${ }^{12}$ Salman M.A. Salman (2013), 'The Nile Basin Cooperative Framework Agreement: a peacefully unfolding African spring?,' Water International, 38:1, 17-29, , p17. DOI: 10.1080/02508060.2013.744273

${ }^{13}$ Jeffrey D. Azarva (2011), 'Conflict on the Nile: International Watercourse Law and the Elusive Effort to Create a Transboundary Water Regime in the Nile Basin', 25 Temple International and Comparative Law Journal. pp. 457- 461.

${ }^{14}$ Broth Ashok Swain (2002), 'The Nile River Basin Initiative: Too Many Cooks, Too Little', SAIS Review, Volume 22, Number 2, Summer-Fall, 293-308, p.294 citing Robert Rangeley, Bocar M. Thiam, Randolph A. Andersen, and Colin A. Lyle (1994), International River Basin Organizations in Sub-Saharan Africa (Washington, DC: World Bank Technical Paper No. 250.

15 Nile Treaty, 1902. Treaty between Ethiopia and the United Kingdom, relative to the frontiers between the Anglo-Egyptian Sudan, Ethiopia, and Eritrea (hereinafter 1902 Treaty). Available from: http://untreaty.un.org/ilc/ documentation/english/a_5409.pdf [Accessed 04 December 2017].
} 
the Blue Nile, Lake Tsana or the Sobat which would arrest the flow of their waters into the Nile except in agreement with His Britannic Majesty's Government and the Government of the Sudan '. ${ }^{16}$ Irrespective of the arguments surrounding validity of the 1902 Treaty, the agreement is non-inclusive and 'merely required Ethiopia not to "arrest" (i.e. cut off) the Nile waters'.17

Another non-inclusive agreement is the 1929 Nile Water Agreement ${ }^{18}$ signed between Egypt and Great Britain on behalf of its colonies (Sudan, Kenya, Uganda, and Tanganyika which is the present day Tanzania). It embodied the following:

'save with the previous agreement of the Egyptian Government, no irrigation or power works or measures are to be constructed or taken on the River Nile and its branches, or on the lakes from which it flows, so far as all these are in the Sudan or in countries under British administration, which would, in such a manner as to entail any prejudice to the interests of Egypt, either reduce the quantity of water arriving in Egypt, or modify the date of its arrival, or lower its level', 19

The 1929 agreement allocated much of the bulk of the annual flow of the River Nile (forty-eight billion cubic meters of water) to Egypt and four billion to Sudan. $^{20}$ The allocation of the 1929 Nile agreements was largely in favor of Egypt and to a limited extent to Sudan. There was expansion of irrigation projects (that caused additional water needs) following the Egyptian revolution in 1952. After the independence of Sudan (in 1956), it forced Egypt to enter into

${ }^{16}$ Id., Art. III.

${ }^{17}$ Elias N. Stebek (2007), 'Eastern Nile at Crossroads: Preservation and Utilization Concerns in Focus', Mizan Law Review Vol. 1 No.1, June 2007, 33-59, p. 52. DOI: dx.doi.org/10.4314/mlr.v1i1.55613

${ }^{18}$ Nile Treaty, 1929. Exchange of notes between Great Britain and Northern Ireland and Egypt in regard to the use of the waters of the River Nile for irrigation purposes, Cairo, May 1929.

19 Id., Art. 4 (b).

20 Paul Howell (1994), 'East Africa's Water Requirements: The Equatorial Nile Project and the Nile Waters Agreement of 1929: A Brief Historical Review', in the Nile: Sharing a Scarce Resource: An Historical and Technical Review of Water Management and Economic and Legal Issues, p.84-85. 
renegotiation. ${ }^{21}$ Finally, the renegotiation culminated in the signing of a Nile water treaty in $1959 .^{22}$

The non-inclusive 1959 Nile water agreement ${ }^{23}$ provides for the 'Full Utilization of the Nile Waters'. According to the agreement, Egypt received 55.5 billion cubic meters and Sudan 18.5 billion cubic meters of the Nile, out of the river's average annual flow of the 84 billion cubic meters. During the last six-decades, Egypt and Sudan had considered their share of 1959 Nile water agreement, as their 'non-negotiable entitlement to the Nile waters'. ${ }^{24}$

The out-dated 1959 legal regime in the Nile Basin bestows almost 'exclusive rights $^{25}$ to Egypt and Sudan to exploit the Nile waters while barring other riparian states from using the Nile waters. Ethiopia refused to recognize the 1959 Nile water treaty and was prompt in asserting that it has the right to exploit the Nile River to the benefits of its citizens. ${ }^{26}$ Ethiopia and other Nile upper riparian states hold a firm position that the 1959 agreement is 'unfair, that it is valid between the two countries only, and that they need to harness the water in a fair and rational manner'. ${ }^{27}$

In 1961, upon initiation of Egypt, Kenya, Tanzania and Uganda, an organization called Hydromet (Hydrometeorological Survey of the Catchments of Lakes Victoria, Kyoga, and Mobutu Sese Seko) was established with the assistance of the United Nations Development Program and the World Meteorological Organization and it was the first basin-wide arrangement. ${ }^{28}$ The purpose of the Hydromet project was to 'evaluate the water balance of the Lake

${ }^{21}$ Broth Ashok Swain, supra note 14, p. 296 citing Peter Wallensteen and Ashok Swain, Comprehensive Assessment of the Freshwater Resources of the World, International Fresh Water Resources: Conflict or Cooperation? (Stockholm: Stockholm Environment Institute, 1997).

${ }^{22}$ Ibid., citing Gabriel R. Warburg (1991), "The Nile in Egyptian-Sudanese Relations," Orient 32, no.4, p. 570.

${ }^{23}$ Nile Treaty, 1959. Agreement between the Arab Republic of Egypt and the Republic of the Sudan for the full utilization of the Nile waters, 1959. 453.

${ }^{24}$ Robert O. Collins (2006), Negotiations and Exploitation of the Nile Waters at the End of the Millennium, Water International, 31:1, 116-126, p.124. DOI: 10.1080/02508060608691921,

${ }^{25}$ Peter Kagwanja (2007), Calming the Waters: The East African Community and Conflict over the Nile Resources, Journal of Eastern African Studies, 1:3, 321-337, p.322. DOI: $10.1080 / 17531050701625565$

${ }^{26}$ Alan Nicol (2003), The Nile: Moving Beyond Cooperation, printed by UNESCO, Division of Water Science, Paris, France. Available at: http//www.unesco.org/water/wwap/pccp (accessed 05 September, 2018), p.13.

27 Mohammed Abdo (2005), 'The Relevance and Contribution of the UN Watercourses Convention toward Resolving the Problems in the Nile Basin', the CEPMLP Internet Journal, Volume 15, Article 8, Dundee University, Scotland, April 2005, p.6.

${ }^{28}$ Robert O. Collins, supra note 24, p.118. 
Victoria catchment area in order to assist in regulating the water level of the lake as well as the water flow of the Nile. Later, Rwanda and Burundi joined in the effort' ${ }^{29}$ However, Hydromet failed to develop an effective basin level cooperation institutional arrangement. ${ }^{30}$

In 1983, upon Egypt's initiative, and following the consent of other Nile river basin countries Sudan, Uganda, Zaire, and the Central African Republic UNDUGU ("Ndugu" is Swahili for brotherhood) was established to serve as a permanent institution to foster basin-wide cooperation beyond the level of hydrological studies. ${ }^{31}$ After the establishment of UNDUGU, members of the organization 'had some common interests in the Nile waters'. 32

In December 1992 at the 67th meeting of UNDUGU in Kampala, six ministers for water resources from Egypt, Sudan, Rwanda, Tanzania, Uganda, and Congo were convinced to 'reorganize the organization into a forum for consultation among the riparians on the utilization of the river's resources for development from scientific and technical matters' ${ }^{33}$ The Technical Cooperation Committee for the Promotion of the Development and Environmental Protection of the Nile (TECCONILE) was regarded as an enhanced basin wide institutional cooperation as compared to the largely dysfunctional UNDUGU. ${ }^{34}$ However, TECCONILE proved another frustrating experience in terms of creating an inclusive and working institutional arrangement. ${ }^{35}$

In March $1998^{36}$, there was a significant development upon the conclusion of an agreement by the Council of Ministers of Water Affairs of the Nile Basin States over the sharing and management of the Nile River, and their new

${ }^{29}$ Broth Ashok Swain, supra note 14, p.301.

${ }^{30}$ Ibid.

${ }^{31}$ Mohamed S. Helal (2013), Inheriting International Rivers: State Succession to Territorial Obligations, South Sudan, and the 1959 Nile Waters Agreement Emory International Law Review, p. 933 citing Korwa Adar (2007), 'The Interface between National Interest and Regional Stability: The Nile River and the Riparian States,' 11 Afr. Soc. Rev. 4, p.8.

${ }^{32}$ Robert O. Collins, supra note 24, p. 118.

${ }^{33}$ Mohamed S. Helal, supra note 31, p. 933 citing Abdel Fattah Metawie (2004), 'History of Co-operation in the Nile Basin', 20 International Journal of Water Resources Development, 47,54.

${ }^{34}$ Robert O. Collins, supra note 24, p. 118.

35 Ibid.

${ }^{36}$ Prior to the 1998 conclusion of an agreement by Council of Ministers of Water Affairs of the Nile Basin States, some preparatory works were underway. In February 1995, the Nile River Basin Action Plan was adopted during the Nile-COM's third meeting in Arusha; in 1996, work had started toward drafting the Nile River Basin Cooperative Framework Agreement by the Panel of experts. 
approval of a new program of action. ${ }^{37}$ This gave birth to a new era of hope and cooperation and it led to the formal commencement of the Nile Basin Initiative (NBI) in February 1999. The NBI was meant to serve an ad-hoc arrangement until the 'Nile river riparian member countries agree on a permanent legal and institutional framework for sustainable development of the Nile Basin' and the majority of the Nile river riparian states $^{38}$ agreed on the CFA in $2010 .{ }^{39}$ It remains to be seen whether CFA will live up to expectations.

\section{Overview of the Watercourses Convention and the CFA}

The UN Watercourses Convention seeks to lay down the basic international norms governing the non-navigational uses of international watercourses. ${ }^{40}$ The key aim of the Convention is to 'ensure the utilization, development, conservation, management, and protection of international watercourses and the promotion of the optimal and sustainable utilization thereof for present and future generations'; whilst 'taking into account the special situation and needs of developing countries'. ${ }^{41}$ As McCaffrey notes, the Convention should be regarded as 'an instrument that reflects a general consensus as to the principles that are universally applicable in the field', irrespective of its ratification. ${ }^{42}$

The Watercourses Convention underlines the importance of data in water resource management and calls on states to share such data ${ }^{43}$, unless "such data is vital to national security' ${ }^{44}$ The Convention also calls on member states to

${ }^{37}$ Broth Ashok Swain, supra note 14, p 419.

${ }^{38}$ On 14 May 2010, four of the Nile riparians (Ethiopia, Tanzania, Uganda and Rwanda) signed the CFA in Entebbe, Uganda, and were joined five days later by Kenya. On 28 February 2011, Burundi joined the five states and signed the CFA. Although the two riparian states South Sudan and the Democratic Republic of Congo indicated their support of the CFA, they have not yet signed it.

${ }^{39}$ Broth Ashok Swain, supra note 14, p. 14.

${ }^{40}$ For a detailed analysis of the Convention, see A. Tanzi and M. Arcari (2001), The United Nations Convention of the Law of International Watercourses - A Framework for Sharing (Kluwer,). See also P. K. Wouters (1999), 'The Legal Response to International Water Conflicts: The UN Watercourses Convention and Beyond', 42 Ger. Y.B. Int'l L., p. 293 in Alistair Rieu-Clarke and Flavia Rocha Loures (2009), Still not in Force: Should States Support the 1997 UN Watercourses Convention? RECIEL 18 (2), p.188.

${ }^{41}$ See Preamble, Watercourses Convention.

${ }^{42}$ Marcella Nanni (2016), Water challenges in the IGAD region: towards new legal frameworks for cooperation, Water International, 41:4, 635-651, p.636.

DOI: 10.1080/02508060.2016.1169620; citing McCaffrey, S.C.(2001). The Contribution of the UN Convention on the Law of the Non-Navigational Uses of International Watercourses. International Journal of Global Environmental Issues, 1(3/4), 250-263.

Doi: 10.1504/IJGENVI.2001.000980

${ }^{43}$ Art 9 of the Watercourses Convention.

${ }^{44}$ Id., Art. 31. 
inform, consult, and if possible negotiate on adverse planned measures along international watercourses. $^{45}$ Part IV of the Convention has some key contemporary international water law principles regarding the preservation of freshwater and marine ecosystems, or reducing pollution and not introducing alien species. ${ }^{46}$ There are some articles on joint management, regulation and protection of installations, ${ }^{47}$ and the responsibility to deal with emergency situations ${ }^{48}$ and armed conflict. ${ }^{49}$ Article 33 deals with the peaceful resolution of disputes.

Nile riparian states have participated in the preparation, and adoption process of the Watercourses Convention. Even though Kenya and Sudan, voted in favor of the Watercourses Convention, ${ }^{50}$ none of the Nile riparians has yet ratified the agreement. ${ }^{51}$ One of the Nile river states, Burundi, voted against the Convention. It is not known why Burundi voted against the Convention, having not been an active participant in the working group. ${ }^{52}$ Ethiopia, Egypt, and Tanzania for different reasons abstained. On the one hand, two upper riparians (Ethiopia and Tanzania) abstained during the adoption of the Convention and they seem to have considered the Convention as 'biased in favour of lower riparians because of its specific and separate mention of the obligation not to cause harm' ${ }^{53}$ Uganda, DRC and Eritrea were absent during the adoption process of the convention. ${ }^{54}$ On the other hand, Egypt, a downstream state, also abstained, concerned that the Convention 'favours upstream riparians because it subordinates the no harm rule to the principle of equitable and reasonable utilization'. 55

The CFA has 44 articles, classified into six parts, which are General Principles, Right and Obligations, Institutional Structure, Subsidiary Institutions, Miscellaneous Provisions, and Final clauses. The CFA lays down some basic

\footnotetext{
${ }^{45}$ Id., Arts. 11-19.

${ }^{46}$ Id., Arts. 20-23.

${ }^{47}$ Id., Arts. 24-26.

${ }^{48}$ Id., Arts. 27-28.

${ }^{49}$ Id., Arts. 29-32.

${ }^{50}$ Mohammed Abdo, supra note 27, p.2.

${ }^{51}$ Joyeeta Gupta (2016), The Watercourses Convention, Hydro-hegemony and

Transboundary Water Issues, The International Spectator, 51:3, 118-131, p.125. DOI: 10.1080/03932729.2016.1198558

${ }_{52}$ Alistair Rieu-Clarke and Flavia Rocha Loures, supra note 40, p.190.

${ }^{53}$ See Salman M.A. Salman (2015), Entry into force of the UN Watercourses Convention: why should it matter?, International Journal of Water Resources Development, 31:1, 416, p.11. DOI: $10.1080 / 07900627.2014 .952072$

${ }^{54}$ Mohammed Abdo, supra note 27, p.2.

${ }^{55}$ Ibid.
} 
principles for the protection, use, conservation and development of the Nile Basin. ${ }^{56}$ The CFA reestablishes the contemporary international water law principle of fair and equitable utilization that each Nile Basin riparian state has the right to use, within its respective territory, the waters of the Nile River Basin in an equitable and fair manner without causing significant harm. ${ }^{57}$ The Nile Basin Initiative was indeed a 'departure in the management of the Nile, for its objective was equitable utilization that would erode historic rights' ${ }^{58}$ The Nile Basin Initiative has sought to ease 'the traditionally hostile Nile riparians and create a spirit of cooperation among them'. ${ }^{59}$

The CFA was signed by six of the riparian states, namely Ethiopia, Rwanda, Tanzania, Uganda, Kenya, and Burundi, and has been ratified only by three, i.e., Ethiopia, Rwanda and Tanzania. ${ }^{60}$ These upstream states signed and ratified the CFA after stalled negotiations, and they realized that 'they had no choice but to resort to the next move: opening the CFA for signature'. ${ }^{61}$ Egypt and Sudan have refused on the ground that the water quota as stipulated in the 1959 bilateral water treaties was not preserved and their current uses and rights have not been legally protected. ${ }^{62}$

\section{The Interface between Watercourses Convention and the CFA}

The Watercourses Convention duly promotes general principles of international water law at global level and it has been replicated in regional watercourses such as the Nile River. ${ }^{63}$ In international watercourses, there is no alternative other than cooperation in order to achieve fair and equitable utilization, the principle of no significant harm, protecting, and preserving shared ecosystems. ${ }^{64}$ The Watercourses Convention seeks 'the comprehensive codification of cooperation obligations' and it explicitly spells out 'the duty to cooperate as one of the contemporary principles of international water law'. ${ }^{65}$ In the same

\footnotetext{
${ }^{56}$ Art 6 of CFA.

${ }^{57}$ Art 4 of CFA.

${ }^{58}$ Robert O. Collins, supra note 24, p. 120.

${ }^{59}$ Id., p. 125.

${ }^{60}$ See the official website of the Nile Basin Initiative at www.nilebasin.org

${ }^{61}$ Tadesse Kassa Woldetsadik (2017), 'The Nile Basin Initiative and the Cooperative Framework Agreement: Failing Institutional Enterprises? A Script in Legal History of the Diplomatic Confront (1993-2016)', Mizan Law Review, Vol. 11, No.1, p. 203. DOI: dx.doi.org/10.4314/mlr.v11i1.7

${ }^{62}$ See Art. 14 (b) of the FA and the annex to the CFA agreement.

${ }^{63}$ Christina Leb (2013), 'The UN Watercourses Convention: the éminence grise behind cooperation on transboundary water resources', Water International, 38:2, 146-155. p.146.

64 Ibid.

65 Ibid.
} 
manner, the CFA incorporates the provisions of the Watercourses Convention on equitable and reasonable utilization, the obligation not to cause significant harm, cooperation and exchange of data and information. ${ }^{66}$

\subsection{Definition of international watercourses}

The Watercourses Convention ${ }^{67}$ defines 'international watercourse' as 'a watercourse, parts of which are situated in different states'. ${ }^{68}$ The Convention confirms the equality of riparian states (sovereign equality) and the entitlement of every riparian state to the equal recognition of rights and status irrespective of their geographical location. ${ }^{69}$ To this end, Watercourse States shall 'cooperate on the basis of sovereign equality, territorial integrity, mutual benefit and good faith in order to attain optimal utilization and adequate protection of an international watercourse'. ${ }^{70}$

It defines the term watercourse to include both 'surface water and ground waters constituting by virtue of their physical relationship a unitary whole and normally flowing into a common terminus'. ${ }^{71}$ This definition includes only underground water connected to surface water. ${ }^{72}$ In other words, the definition in the Watercourses Convention includes 'groundwater that is hydrologically connected with surface water, which is in fact the case for much of the world's groundwater' ${ }^{73}$ It does not include international aquifers that are not connected to surface waters. ${ }^{74}$

By focusing only on connected ground and surface waters and not river basins, the Convention limited 'the control of the regime to the water as opposed to the land in watersheds'. ${ }^{75}$ It does not incorporate the expansion of the definition of groundwater under the Seoul Rules which includes transboundary aquifers that are not connected with the surface waters of an international

${ }^{66}$ Marcella Nanni, supra note 42, p. 636, citing McCaffrey, S. C. (2001). International Water Law for the 21 st Century: The Contribution of the UN Convention. 118 Water Resources Update 11.

${ }^{67}$ At the outset, it was not found necessary to determine the scope of the expression 'international watercourse'. In fact, the organ in charge of drafting the Watercourses Convention did not define this expression until it adopted a full set of draft articles on the topic in 1991. The definition adopted in 1991 is substantially unchanged in the Convention. See Stephen C. McCaffrey, supra note 2, p.1.

${ }^{68}$ Art 2 (b) of the Watercourse Convention.

${ }^{69}$ Joyeeta Gupta, supra note 51, p.122.

${ }^{70}$ Art 8 (1) of the Watercourses Convention.

${ }^{71}$ Art 2 (a) of the Watercourses Convention.

${ }^{72}$ Salman M.A. Salman, supra note 53, p.8.

${ }^{73}$ Stephen C. McCaffrey, supra note 2, p.2.

${ }^{74}$ Salman M.A. Salman, supra note 53, p.8.

${ }^{75}$ Joyeeta Gupta, supra note 51, p.124. 
drainage basin. ${ }^{76}$ Although the International Law Commission (ILC) adopted restrictive approach in defining watercourse, the ILC had issued a parallel resolution suggesting that the Watercourses Convention regulate other characteristics of underground water. ${ }^{77}$

CFA distinguishes Nile watercourse into 'Nile River Basin' and 'Nile River System'. It defines Nile River Basin as 'the geographical area determined by the watershed limits of the Nile River System of waters; this term is used where there is a reference to environmental protection, conservation or development'. ${ }^{78}$ It defines Nile River System as 'the Nile River and the surface waters and ground waters which are related to the Nile River; this term is used where there is a reference to utilization of water'. ${ }^{79}$ The wording appears to be similar to the notion of 'river ecosystem expression employed by the ILC during the course of drafting of the UN Watercourses Convention - to refer to river streams as such and the waters they carry'. 80

During the CFA negotiation, Egypt argued that Nile River System shall apply to both 'environmental protection and water allocation'. ${ }^{81}$ This would mean, according to Egypt, Nile River System should not only include the water allocation as per the 1959 Nile Agreement between Egypt and Sudan (blue water) but should also include the underground and surface water that falls in all the Nile riparian states (green water) and should be subject to regulation. ${ }^{82}$ Ethiopia, on the other hand, argued to limit the scope of the Nile river system to refer to the Nile river streams discourse 'because of its clear geographical implication beyond the water bodies'. ${ }^{83}$

The Watercourses Convention and the CFA have employed a restrictive definition of watercourse and Nile River system respectively as far as utilization and regulation are concerned. This restrictive interpretation seems to have considered the concerns of many upstream riparian states as it places very limited restrictions on the notion of the sovereignty of the states. ${ }^{84}$ The Watercourses Convention and the CFA limit 'each basin state's sovereign

\footnotetext{
${ }^{76}$ Salman M. A. Salman (2007), 'The Helsinki Rules, the UN Watercourses Convention and the Berlin Rules: Perspectives on International Water Law', International Journal of Water Resources Development, 23:4, 625-640, p. 632.

DOI: 10.1080/07900620701488562

${ }^{77}$ For the text of this Resolution, see, Salman M. A. Salman (Ed.), 1999, Groundwater Legal and Policy Perspectives, World Bank Technical Paper No. 456, p. 235.

${ }^{78}$ Art 2 (a) CFA.

${ }^{79}$ Art 2 (b) CFA.

${ }^{80}$ Tadesse Kassa Woldetsadik, supra note 61, p.212.

${ }^{81}$ Salman M.A. Salman, supra note 12, p.23.

${ }^{82}$ Ibid.

${ }^{83}$ Tadesse Kassa Woldetsadik, supra note 61, p. 212.

${ }^{84}$ Id., p. 213.
} 
discretion with regard to the utilization of the main channels of the Nile, tributaries, as well as sub-tributaries, rivulets and groundwater systems availed throughout the basin - so long as they form part of a unitary whole'. ${ }^{85}$

\subsection{Principles of equitable utilization and no significant harm}

Equality of rights of co-riparians is one of the key principles of the Watercourses Convention and CFA and this has been manifested in both agreements through the incorporation of principles of equitable utilization and no significant harm. The provisions of the CFA on equitable and reasonable utilization and the obligation against causing significant harm are some of the most unsettled issues and the same is true with regard to the Watercourses Convention. ${ }^{86}$ The Watercourses Convention which embodies provisions on equitable and reasonable utilization and the obligation against causing significant harm (Articles 5 to 7) was adopted with 38 affirmative votes, 22 abstentions and four negative votes, namely those of China, France, and Turkey including of the Nile river riparian state, Tanzania. ${ }^{87}$

\subsubsection{The Principle of equitable and reasonable utilization}

The principle of equitable utilization has received wide acceptance, and its status is reinforced by international water agreements, state practice and international judicial decisions. Article 5(1) of the Watercourses Convention provides that:

Watercourse States shall in their respective territories utilize an international watercourse in an equitable and reasonable manner. In particular, an international watercourse shall be used and developed by watercourse States with a view to attaining optimal and sustainable utilization thereof and benefits therefrom, taking into account the interests of the watercourse States concerned, consistent with adequate protection of the watercourse.

In a similar fashion, Article 4 of the CFA (in the context of the Nile basin) has reproduced the above provision:

Nile Basin States shall in their respective territories utilize the water resources of the Nile River system and the Nile River Basin in an equitable and reasonable manner. In particular, those water resources shall be used and developed by Nile Basin States with a view to attaining optimal and sustainable utilization thereof and benefits therefrom, taking into account the

\footnotetext{
${ }^{85}$ Ibid.

${ }^{86}$ Salman M.A. Salman, supra note 12, p. 21.

${ }^{87}$ Attila Tanzi, The completion of the preparatory work for the UN Convention on the Law of International Watercourses, Nature Resources Forum, Vol. 21. No. 4, pp. 239-245, 1997, p. 242.
} 
interests of the Basin States concerned, consistent with adequate protection of those water resources. Each Basin State is entitled to an equitable and reasonable share in the beneficial uses of the water resources of the Nile River system and the Nile River Basin.

One of the core principles in the Watercourses Convention and the CFA -the principle of equitable and reasonable utilization- is a fundamental principle of contemporary international water law transboundary water resources, ${ }^{88}$ and it constitutes "the conceptual backbone of international water law, ${ }^{89}$ thereby entitling every riparian country, 'within its territory, to a reasonable and equitable share in the beneficial uses of the waters of an international river'.$^{90}$ The CFA has adopted the principle of equitable and reasonable utilization in the context of the Nile River and many of the wordings are inspired by the normative contents of the Watercourses Convention. Therefore, it is safe to conclude that the CFA's normative contents of the principle of equitable and reasonable utilization are borrowed from the Watercourses Convention. ${ }^{91}$

With regard to the application of the equitable utilization principle, the Watercourses Convention entrusts states that have different interests with the primary responsibility (including interpretation of the factors and circumstances under Art. 6). On the other hand, the CFA seems to have anticipated the problems, and Art. 4(6) states that the Nile basin shall only observe rules and procedures established by the Nile River Basin Commission for the effective implementation of the equitable principle. ${ }^{92}$ It thus seems that the CFA leaves no room for unilateral interpretation. ${ }^{93}$

The Nile River Basin Commission is established by the Nile river basin states, and the final policy-related decisions are made by the Conference of Heads of State and Government which is composed of Heads of State and

${ }^{88}$ Stephen C. McCaffrey, The Law of International Watercourses: Non-Navigational Uses (2001), at 245-246, pp. 325 and 345 in Dereje Zeleke Mekonnen (2010), 'The Nile Basin Cooperative Framework Agreement Negotiations and the Adoption of a 'Water Security' Paradigm: Flight into Obscurity or a Logical Cul-de-sac?', The European Journal of International Law Vol. 21 no. 2 , p. 437.

${ }^{89}$ Nollkaemper, 'The Contribution of the International Law Commission to International Water Law: Does it Reverse the Flight from Substance?', 27 Netherlands Yrbk Int'l L (1996) 44 in Dereje Zeleke Mekonnen, supra note 88, p. 437.

${ }^{90}$ Caponera, 'The Legal Status of the Shatt-al-Arab (Tigris \& Euphrates) River Basin', 45 Austrian J Public and Int'l L (1993) 156 in Dereje Zeleke Mekonnen, supra note 88, p.437 .

${ }^{91}$ Musa M. Abseno (2013), The influence of the UN Watercourses Convention on the development of a treaty regime in the Nile River Basin. Water International, 38(2), 192203. p.198. Doi: $10.1080 / 02508060.2013 .782798$

${ }^{92}$ Comment from one of the reviewers of this article.

${ }^{93}$ Ibid. 
Government of Nile Basin States. ${ }^{94}$ The executive organ of the Nile River Basin Commission, the Council of Ministers, which is composed of Minister for Water Affairs of each Nile Basin State and other relevant ministers, decide on the principles of the CFA including the application of the principle of fair and equitable utilization of the Nile River by consensus. ${ }^{95}$ The consensus decisionmaking processes of the Nile River Basin Commission gives the Nile River states a room for interpretation of the principle of fair and equitable utilization of the Nile River according to list of factors that advances their respective national interests, and this can create vicious circle of disputes.

The Watercourses Convention and CFA have relatively similar substantive content in enumerating the list of factors such as population, current and potential use, geography and others that should be taken into consideration by each Nile river basin state in the application of the principle of equitable and reasonable utilization. CFA goes further and supplements two additional factors adopted from the Helsinki Rules (Article V), i.e., water contribution of each Nile riparian state and the extent of the drainage basin within each Nile river state. $^{96}$

The Watercourses Convention has the non-exhaustive list of criteria for the determination of the utilization of an international watercourse and 'leaves the weighting of these criteria to be decided on a case-by-case basis' ${ }^{97}$ It is not clear which list of criteria is applied for water allocation purpose. ${ }^{98}$ The CFA has taken the same approach that decisions regarding the application of the lists of the factors of principles of equitable and reasonable utilization can be adapted within the context of the Nile basin. However, the Watercourses Convention in its 'current formulations, cannot guide adjustments to current water shares between the countries'. 99

The Watercourses Convention has transmitted one of its serious weaknesses to the CFA 'which limits its utility as a working document by permitting the riparian states in dispute to engage in almost endless discussion over all the

${ }^{94}$ Article 20 (1) of the CFA.

${ }^{95}$ Article 23 (5) of the CFA. The Technical Advisory Committee of the Nile River Basin Commission makes recommendations to the Council of Water Ministers on decisions regarding 'the determination of equitable and reasonable use of water in each riparian country taking into consideration the factors provided in Article 4, paragraph 2'. See Article 26 (5) of the CFA.

${ }^{96}$ Abseno, supra note 91, p.198.

${ }^{97}$ Christina Leb, supra note 63, p.151.

${ }^{98}$ Joyeeta Gupta, supra note 51, p.124.

${ }^{99}$ Bruce Lankford (2013), 'Does Article 6 (Factors Relevant to Equitable and Reasonable Utilization) in the UN Watercourses Convention misdirect riparian countries?', Water International, 38:2, 130-145, p.130. DOI: 10.1080/02508060.2013.780687 
factors which might be considered'. ${ }^{100}$ As a result, the Watercourses Convention is not helpful in providing guidelines as to how the lists of factors are to be assessed. This makes it difficult to apply the CFA in a context of potential water dispute. ${ }^{101}$ The same can be concluded about the application of equitable and reasonable utilization in the Nile river basin.

While Article 6 of the Watercourses Convention, inter alia, intends 'to closely guide water allocation', it 'leaves unresolved the level of detail and other mechanisms required to take water allocation to a satisfying or unambiguous conclusion'. ${ }^{102}$ Article 6 'runs the risk of steering riparians towards equalizing shares of water resources within transboundary watercourses while creating an illusion of guiding equitable water allocation'. ${ }^{103}$ Unless this possible misdirection is recognized, Article 6 may have 'limited utility'. ${ }^{104}$ This shortcoming and limitations are also reflected in the CFA since the CFA is designed based on the Watercourses Convention.

In due course of negotiations toward addressing the utilization of an international watercourse, the Watercourses Convention has formulated the fundamental principles of equitable and reasonable utilization of the water in ambiguous terms and has opened the room for "normative construction of ambiguity'. ${ }^{105}$ It has been argued that 'ambiguity is . . . commonly incorporated in agreements pertaining to natural resources, and water in particular', ${ }^{106}$ and the Watercourses Convention ambiguously 'provides something for everyone, enabling all sides to claim partial victory while not providing any tools for resolving competing claims'. 107

The ambiguity of the Watercourses Convention pertaining to the normative contents of principles of equitable and reasonable utilization is reflected by the marathon negotiations process ${ }^{108}$ and one may argue that this is what is

${ }^{100}$ Peter Beaumont (2000), 'The 1997 UN Convention on the Law of Non-navigational Uses of International Watercourses: Its Strengths and Weaknesses from a Water Management Perspective and the Need for New Workable Guidelines', International Journal of Water Resources Development, 16:4, 475-495, DOI: 10.1080/713672536, p475.

${ }^{101}$ Id., p. 482.

${ }^{102}$ Bruce Lankford, supra note 99, p.131.

${ }^{103}$ Ibid.

${ }^{104}$ Ibid.

${ }^{105}$ Fischhendler, 'Ambiguity in Transboundary Environmental Dispute Resolution: The Israeli Jordanian Water Agreement', 45 J Peace Research (2008), DOI 1177/0022343307084925, at 80, in Dereje Zeleke Mekonnen, supra note 88 , p.436 .

${ }^{106}$ Ibid.

${ }^{107}$ Ibid.

${ }^{108}$ The proposal for a convention on the subject was challenged as premature and unwarranted intervention into the business of the riparians. See ILC, Verbatim Record, Yearbook of the International Law Commission (1986), i. It took the ILC over two 
rationally expected of a framework convention. ${ }^{109}$ Applying the basic principles of equitable and reasonable utilization of an international watercourse taking into consideration the specific characteristics of the Nile River Basin and other similar river basins and riparian states is, without doubt, a very difficult task. ${ }^{110}$ Yet, the controversy surrounding the ambiguity pertaining to the regulation and utilization of an international watercourse is no justification to characterize the entire discourse as one featured with ambiguity. After all, the Watercourse Convention represents the on-going 'codification and progressive development of rules of international law regarding non-navigational uses of international watercourses'.111

In spite of unsettled issues in connection with the application of a reasonable and equitable reallocation agreement for transboundary watercourses and its ambiguous application in the Nile River Basin, there is no alternative mechanism better than the framework under the Watercourses Convention. ${ }^{112}$ It should, thus, not be overlooked that for Nile riparians, the Watercourses Convention 'provides a starting point for the negotiation of agreements relating to specific watercourses, and, in the absence of any applicable agreement, it sets basic parameters governing the conduct of states riparian to those watercourses'. 113

\subsubsection{The Obligation not to cause significant harm}

Article 7 of the 1997 Convention provides that "Watercourse States shall, in utilizing an international watercourse in their territories, take all appropriate measures to prevent causing of significant harm to other watercourse states", and it further states: "The emphasis on prevention is important, since it is often difficult to stop or modify an activity once it has began, and it can be very complicated and expensive, if indeed it is possible, to remedy harm once

decades to complete the task and the Convention was adopted by the General Assembly (GA Res A/RES/51/229 of 21 May 1997). See text in 36 ILM (1997) 700.

${ }^{109}$ It 'identifies basic principles on which the parties can agree regardless of the adoption of further agreements covering specific watercourses'; and 'provides a flexible basis for the development of institutions and the harmonization of laws and policy for each regional watercourse': P.W. Birnie and A.E. Boyle, International Law and the Environment (2nd edn, 2002), at 329 in Dereje Zeleke Mekonnen, supra note 88, p.43.

110 The two core principles (Arts 5 and 7) set the doctrinal parameters in which divergent riparian interests should be brought to a compromise by taking into account all the relevant factors (Art. 6) in a transparent and cooperative atmosphere (Arts 8,9).

${ }^{111}$ See Watercourses Convention, Preamble, at para. 3.

${ }^{112}$ Dereje Zeleke Mekonnen, supra note 88, p. 437.

${ }^{113}$ Stephen C. McCaffrey (2001), 'The Contribution of the UN Convention on the Law of the Non-Navigational Uses of International Watercourses', 1 Int'l J Global Environmental Issues, p. 261. 
caused". ${ }^{114}$ This is reproduced in the context of the Nile river basin in Article 5 of the CFA which reads:

Nile Basin States shall, in utilizing Nile River System water resources in their territories, take all appropriate measures to prevent the causing of significant harm to other Basin States.

Article 7 of the Watercourses Convention and Article 5 of the CFA deal with the obligation not to cause significant harm and is an 'expression of the sic utere principle'. ${ }^{115}$ In the Convention and the CFA there seems to be tension between the obligation dealing with 'equitable and reasonable utilization', and with its 'obligation not to cause significant harm'. It seems for both to be achieved at the same time without problems. ${ }^{116}$ It can be safely concluded that one area of interface between the Watercourses Convention and CFA is the recognition of an obligation on riparian states not to cause significant harm in the course of their utilization of water resources within their territories.

\subsection{Prioritization of water use rights}

One the fundamental issues addressed by the Watercourses Convention is the prioritization of water use rights. The general rule is that in absence of agreement or custom to the contrary, no use of an international watercourse enjoys inherent priority over other uses' ${ }^{117}$ Article 10 of the Watercourse Convention states the correlation between different kinds of uses, and provides that 'no use of an international watercourse enjoys inherent priority over other uses'. ${ }^{118}$ Conflict between uses of such watercourse "shall be resolved with reference to Articles 5 to 7 (equitable and reasonable use of water and the principle of non significant harm)'. ${ }^{119}$ Moreover, the Watercourses Convention states that in the event of a conflict, it should be resolved 'with special regard being given to the requirements of vital human needs' ${ }^{120}$

United Nations General Assembly has held that 'in determining 'basic human needs', special attention is to be paid to providing sufficient water to sustain human right, including both drinking water and water required for production of food in order to prevent starvation'. ${ }^{121}$ Thus, drinking water is the most vital human need. It implies that water for cooking and washing to

\footnotetext{
${ }^{114}$ Stephen C. McCaffrey, supra note 2, p.3.

${ }^{115}$ Peter Beaumont, supra note 100, p. 482.

${ }^{116}$ Ibid.

${ }^{117}$ Article 10 of the Watercourses Convention.

${ }^{118}$ Id., Art. 10 (1).

${ }^{119}$ Ibid.

${ }^{120}$ Id., Art. 10 (2).

${ }^{121}$ Salman M.A Salman (2014), The human Right to Water and Sanitation: is the Obligation Deliverable?, 39:7, Water International 969-982, p. 971.
} 
maintain public health standards also fall within the scope of vital human needs. Likewise, Article 3(14) of the CFA recognizes the 'social and economic value' of water and states that 'utilization should give priority to its most economic use, taking into account the satisfaction of basic human needs and the safeguarding of ecosystems'. The CFA has thus afforded absolute protection to basic human needs and their normative content seems to be inspired by the Watercourse Convention.

Article 10 of the UN Watercourses Convention is relatively specific than the CFA when it comes to prioritizing water use rights except in the context of basic human needs, in respect of which both are in harmony. There is mismatch between the phrases in the Convention and the CFA with regard to clarity of principle in establishing which types of water uses shall be accorded priority in any given setting. ${ }^{122}$

On the other hand, the CFA goes beyond the Convention, by clearly incorporating new guiding principles relevant to the allocation of waters -such as the principle that 'water shall have social and economic value'. Applying economic values in the Nile entails giving priority to the water's most economic uses (without compromising social uses and environmental protection). ${ }^{123}$ This is a great departure from the equitable use principle of the UN Watercourses Convention -since it affects the order of priority accorded to irrigation, industrial waters, aquaculture, tourism, hydro-power etc. ${ }^{124}$ In view of such different standards for setting a test in prioritizing water use rights, the Watercourses Convention and CFA still suffer from common problems. The 'equitable use' principle of the UN Watercourses Convention and the phrase 'social and economic value' used in CFA (to define a standard of prioritization of water use) seem to need further clarity in future frameworks.

\subsection{Duty to exchange data and information on planned measures}

The duty to exchange data and information on planned measures is different from the regular exchange of data and information. The Watercourses Convention imposes obligation on state parties to exchange (on a regular basis) readily available data and information on the condition of the watercourse. ${ }^{125}$ In a similar manner, the CFA has adopted the principle of exchange of data and information concerning the Nile River Basin. ${ }^{126}$ The Watercourses Convention envisages that the regular exchange of data and information may not be confined

\footnotetext{
${ }^{122}$ Comment from one of the reviewers of this article.

${ }^{123}$ Ibid.

${ }^{124}$ Ibid.

${ }^{125}$ Art. 9 of the Watercourses Convention.

${ }^{126}$ Art. 3(10) of the CFA.
} 
to already available information that is not readily available. On the other hand, the CFA only imposes reciprocal obligations to exchange data and information that are 'readily available and relevant'. ${ }^{127}$

The duty to cooperate is one of the contemporary principles of international water law that is unequivocally recognized in the Watercourses Convention and the CFA. This includes the duty to exchange data and information on planned measures. Article 11 lays down the general duty to exchange, consult and negotiate information concerning planned measures, and it explicitly makes it an obligation to 'exchange information and consult each other and, if necessary, negotiate on the possible effects of planned measures on the condition of an international watercourse'. Moreover, the Watercourses Convention imposes an obligation on the planning state to adopt and notify measures that may have the potential adverse effects on other riparian states and the planning state must exchange all proper and suitable information. ${ }^{128}$ In connection with notification on planned measures, the Watercourses Convention states that 'before a watercourse state implements or permits the implementation measures which may have a significant adverse effect upon other watercourse states, it shall provide those states with timely notification thereof'. ${ }^{129}$

The Watercourses Convention imposes an obligation on the potentially affected riparian states to reply, study and evaluate the transmitted information and its potential adverse effects in connection with planned measures within a maximum period of six months. ${ }^{130}$ The same Convention lays down an obligation on the potentially affected riparian states to communicate their assessment of the potential adverse effects of the planned measures to the notifying riparian states within six months. ${ }^{131}$ The Watercourses Convention aims to ensure the equitable participation of notifying state and potentially affected riparian states. ${ }^{132}$ The notifying state may be asked for additional appropriate data and information within six months which may be extended for an additional period of six months and the planned measure will remain in limbo during that period. ${ }^{133}$ The notifying state shall not within the timeframe of six months and possible

\footnotetext{
${ }^{127}$ Art 3 (10) of the CFA.

${ }^{128}$ Art 12, Watercourses Convention.

${ }^{129}$ Ibid.

${ }^{130}$ Ibid.

${ }^{131}$ Id., Art. 13.

132 Owen McIntyre (2013), "Utilization of shared international freshwater resources -the meaning and role of 'equity' in international water law", Water International, 38:2, 112 129, DOI: 10.1080/02508060.2013.779199, available at http://www.tandfonline.com p.117. (Accessed on 11-Mar-2017).

${ }^{133}$ See Article 14. Watercourses Convention.
} 
extension of another six months ${ }^{134}$ implement or permit the implementation of the planned measures without the consent of the notified states'. ${ }^{135}$

If the notified riparian state reaches at the conclusion that there is no adverse impact, then the notifying state can go ahead with the planned measures. If the potentially affected state reaches at a different conclusion, it shall communicate its evaluation of the impact assessment of the planned measure within the aforementioned time framework. ${ }^{136}$ Then, negotiations must naturally follow with the objective of reaching an 'equitable resolution of the situation' ${ }^{137}$ within the conceptual framework of the Watercourses Convention. The Convention requires good faith during the course of the negotiations. ${ }^{138}$

The Watercourses Convention allows the notifying state to go ahead with the planned measures even in the presence of adverse effect where there are emergency situations such as health, or security reasons. ${ }^{139}$ However, the other watercourse states must be informed thereof; the notification procedure described above must be initiated immediately afterwards; and the principle of equitable and reasonable utilization, as well as the no-significant harm rule, will remain in full effect. ${ }^{140}$

The duty to exchange data and information pertaining to planned measures has been one of the most contentious issues during the course of the CFA negotiations. The CFA has adopted some of the normative contents of the Watercourses Convention on exchange of data and information in connection with planned measures. The CFA stipulates the principle that 'the Nile basin states shall exchange on planned measures through the Nile River Basin Commission'. ${ }^{141}$ In the earlier draft of the CFA, the procedural rules pertaining to exchange of data and information on the planned measures were borrowed from the Watercourses Convention; and all Nile river riparian states except Ethiopia supported it. ${ }^{142}$ Egypt and Sudan pushed for stringent notification, consultation and negotiation procedures based on the framework of the

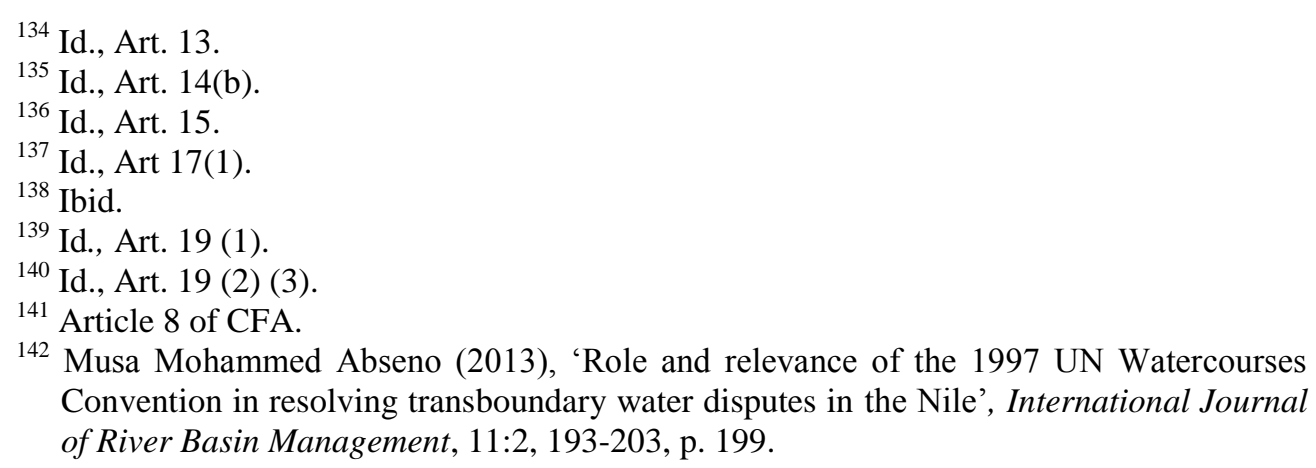

DOI:10.1080/15715124.2013.811415, available at:

http://www.tandfonline.com/loi/trbm20 (Accessed on 11-Mar-17). 
Watercourse Convention. ${ }^{143}$ Egypt strongly argued that evaluation and authorization of any planned measures along the Nile River must be decided through general agreement and must be accompanied by mandatory procedures. ${ }^{144}$

Ethiopia's objection to the proposal (forwarded principally by Egypt) promoted the notion that the issue of planned measures could be accommodated through the regular exchange of data and information. ${ }^{145}$ Ethiopia's objection of the detailed Watercourses Convention pertaining to planned measures was based on 'fears of negative effect which its application may generate' because 'upriver projects would be blocked (or vetoed against)' in the absence of basin-wide consent, 'or at best, the proposals would be subjected to rigorous procedural processes hindering the implementation of pressing national development schemes on the Nile'. ${ }^{146}$ Ethiopia further suggested that the issue of planned measures becomes 'relevant if and only if a water-sharing arrangement acceptable to the basin states is put in place'. ${ }^{147}$ The detailed procedural rules of the Watercourses Convention on planned measures were removed from the contents of the CFA and procedural details were left to the future Nile River Basin Commission. ${ }^{148}$

The CFA chose to adopt a more general principle that can enable the Nile basin states to exchange information on planned measures through the Nile River Basin Commission. ${ }^{149}$ Consequently, the Watercourses Convention and the current contents of the CFA regarding the procedures concerning planned measures are different. The CFA adopts a less detailed principle that only requires:

'the regular and reciprocal exchange among states of the Nile River Basin of readily available and relevant data and information on existing measures and on the condition of water resources of the basin, where possible in a form that facilitates its utilization by the states to which it is communicated'. ${ }^{150}$

Thus, it can be concluded that the robust procedural rules pertaining notification and consultation on planned measures, similar to those under the Watercourses Convention, have not been incorporated in the CFA. The ramification of such divergent approach is that Nile River states (and the upstream countries in particular) may be reluctant to notify and consult planned

\footnotetext{
${ }^{143}$ Tadesse Kassa Woldetsadik, supra note 61, p. 221.

${ }^{144}$ Ibid.

145 Ibid.

${ }^{146}$ Ibid.

${ }^{147}$ PoE Final Report, 2000, p. 17.

${ }^{148}$ Musa Mohammed Abseno, supra note 142, p. 199.

${ }^{149}$ Ibid.

${ }^{150}$ Art. 7 of the CFA.
} 
measures along the Nile River. The absence of mutually acceptable procedural arrangements pertaining to any planned measures along the Nile River within the CFA could trigger tensions and confrontations among the Nile riparian states. The adverse effect of any planned measures along an international watercourse can be avoided if detailed procedural arrangements are adopted within the CFA.

\subsection{Potential fate of existing and future agreements}

States have the liberty to enter into water treaties which 'apply and adjust' the normative contents of the Convention to a specific river basin. ${ }^{151}$ The Watercourses Convention will serve as the framework agreement for future watercourse agreements, and once such agreements are concluded, it will not alter the rights and obligations provided therein. According to Article 3, the Watercourses Convention will not supersede provisions contained in existing watercourse agreements, and will not 'affect the rights or obligations' thereunder. ${ }^{152}$ This provision aims to open a room for ample flexibility in order to contextualize the Watercourses Convention in the context of specific river basins. The contents of the Watercourses Convention aim to 'address the concerns of those States that felt that a mandatory review of the 3,600 or so existing watercourse agreements, upon entry into force of the Convention, would be unduly burdensome'. ${ }^{153}$

Other states, such as, Ethiopia, however, felt that harmonization of obligations between the current water agreements and the Watercourses Convention must be boldly capitalized. ${ }^{154}$ Article 3 was therefore the product of two very divergent views and unsurprisingly did not satisfy all. Ultimately, 35 countries voted in favour of the revised text, while 3 countries (Ethiopia, France and Turkey) voted against it, and 22 abstained. ${ }^{155}$ Thus, the Watercourses Convention envisages harmonization between existing agreements and the Convention. Indeed, it is often the case that 'negotiations of an international agreement are aimed not only at the elaboration of provisions governing certain

${ }^{151}$ Art. 3(3) of the Watercourse Convention.

${ }^{152}$ Id., Art. 3(1).

153 See Egypt's statement explaining its abstention, in United Nations General Assembly, Fifty-First Session, Ninety-Ninth Plenary Meeting (UN Doc. A/51/PV.99, 21 May 1997) (Voting Records), at 10 in Alistair Rieu-Clarke and Flavia Rocha Loures, supra note 40, p.189.

154 See Ethiopia's statement explaining its abstention, in ibid., at 9 -10.

${ }^{155}$ Sixth Committee of the United Nations General Assembly, Summary Record of the First Part of the Sixty-Second Meeting (UN Doc. A/C.6/51/SR.62, 29 August 1997), at p. 6 in Alistair Rieu-Clarke and Flavia Rocha Loures, supra note 40, p.189. 
aspects of the subject matter, but also specifically at the avoidance of explicit provisions on other aspects'. ${ }^{156}$

The CFA, on the other hand, finds itself at logger-heads with the past colonial water agreements and is meant to replace all previous non-inclusive water agreements on the Nile. The CFA at the request of Egypt and Sudan has incorporated 'Water Security' ${ }^{157}$. However, CFA's non-legal and politically loaded terminology of 'water security' is unique as there are no parallel international water law instruments (notably, the 1966 Helsinki Rules and the UN Watercourses Convention) that embody the concept of water security. ${ }^{158}$

The Watercourses Convention also envisages that if possible, the state party, signatory to the Convention, can harmonize previous agreements in force with the basic principles of the Convention. ${ }^{159}$ Certainly, this provision does not entail the obligation to negotiate the revision of an existing watercourse agreement that does not conform with the basic principles of the Convention. ${ }^{160}$ Thus, it can be concluded that the Watercourses Convention bears little influence when it comes to harmonizing previous agreements and CFA, notably with the clear reservation of Egypt and Sudan.

\subsection{Dispute resolution mechanism}

The UN Charter requires member states to settle their disputes through peaceful means. ${ }^{161}$ Water resources are prone to conflicts and the UN Watercourses Convention envisages peaceful settlement of disputes, which includes negotiation, good offices and mediation, fact-finding and inquiry, conciliation and judicial means. ${ }^{162}$ The CFA has also adopted means of dispute settlement mechanisms including fact-finding commission. The Watercourses Convention and the CFA compel disputant parties to settle their differences through the requirement of impartial fact-finding commission if the parties to the water dispute fail to resolve their dispute by all other available means. ${ }^{163}$

\subsection{Institutionalization of cooperation}

With regard to cooperation, the Watercourses Convention promotes the institutionalization of cooperative water resources utilization, management, development and conservation. ${ }^{164}$ Joint commissions or other alternative

\footnotetext{
${ }^{156}$ Attila Tanzi, supra note 87, p. 240.

${ }^{157}$ Article 3(15) of the CFA.

${ }^{158}$ Dereje Zeleke Mekonnen, supra note 88, p.437.

${ }^{159}$ Art 3 (2) of the Watercourses Convention.

${ }^{160}$ Attila Tanzi, supra note 87, p.240.

${ }^{161}$ Art 1(4) of the UN Charter.

${ }^{162}$ Article 33 of the Watercourse Convention.

163 Ibid; and Art 33(1)(b) and Annex of CFA.

${ }^{164}$ Art. 8(2) of the Watercourses Convention.
} 
arrangements are vital tools for the institutionalization of cooperation. They provide important venue for continuous communication among riparian states at technical and political levels. Acknowledging this important role, the Convention refers to the 'experience gained through cooperation in existing joint mechanisms and commissions in various regions'. 165

In a similar fashion, CFA calls for the establishment of joint mechanisms of a permanent Nile River Basin Commission through which riparian states will have the platform to communicate on the utilization, management, development, and conservation of the Nile River. ${ }^{166}$ Article 16 of the CFA states the purpose and objective of the Commission, which has three main objectives:

a) Promote and facilitate the implementation of the principles, rights and obligations of the Agreement;

b) Serve as an institutional framework for cooperation among Nile Basin States in the use, development, protection, conservation and management if the Basin and its water; and

c) Facilitate closer cooperation among states and peoples of the Nile River Basin in social, and culture fields. ${ }^{167}$

The mandate of the Nile River Basin Commission further includes additional functions with regard to dispute settlement, information exchange and cooperation. ${ }^{168}$ Article 33 of the CFA gives the Nile River Basin Commission some role in dispute settlement among the Nile River riparian states. It urges the member states to use the Nile River Basin Commission as mediator or conciliator between the disputing parties. ${ }^{169}$ Thus, it is safe to conclude that the CFA embodies schemes toward the institutionalization of cooperation based on the Watercourses Convention.

\section{Concluding Remarks}

The Watercourses Convention has laid down the foundation in the codification of customary international law on non-navigational uses of international watercourses. It has a significant contribution in strengthening and laying down solid foundational rules with regard to substantive and procedural rules on the

165 Ibid.

${ }^{166}$ Nile States: Permanent River Basin Commission to be Established, Africa Research Bulletin: Economic, Financial and Technical Series, August 2007, Vol.44(6), p.17434A17434B

${ }^{167}$ Art. 16 of the CFA.

${ }^{168}$ Shams Al Din Al Hajjaji. The Long Empty Canyon: A Study of the Old/New Legal Problems of the Nile Basin, Journal of Water Resources and Ocean Science, Vol. 2, No. 5, 2013, p. 141-154, p. 146. Doi: 10.11648/j.wros.20130205.22

169 Art 16 (1) of the CFA. 
regulation, utilization, and preservation of transboundary watercourses. The impact of the Watercourses Convention is indeed visible on a number of international watercourse agreements, and it is more evident in the Nile River basin.

The CFA is the leading sub-regional legal instrument in regulating the utilization and preservation of the Nile River and many of its substantive and procedural rules are influenced by the models adopted by the Watercourses Convention. The general duty to cooperate in the utilization of an international watercourse, adherence to the general obligations of fair and equitable utilization of water resources, the duty not to cause significant harm are among the leading principles that are embodied in the Watercourses Convention and the CFA. The CFA has also relied heavily on the factors that should be taken into consideration in the determination of fair and equitable utilization of international water resources.

Moreover, the Watercourses Convention has shaped the procedural contents of the CFA such as the duty to exchange information, settlement of disputes and the institutionalization of cooperation. The CFA has also inherited many of the limitations of the Watercourses Convention such as the interplay between determination of fair and equitable utilization of international water resources and the duty not to cause significant harm. The fate of existing and future water agreements and their status is still unsettled in the CFA, and the impact of the Watercourses Convention was limited in this regard.

The influence of the Watercourses Convention on the general duty to exchange information is limited in the CFA, and it can be among the points of reference (to avoid potential water conflicts) when CFA adopts some robust and elaborated procedures on the general duty to notify, consult and negotiate on planned measures. Generally, however, the Watercourses Convention has a significant influence on the Nile River Basin Cooperative Framework Agreement (CFA). In the current era of conflict of interests among upper and lower riparians and potential water insecurity, it is hoped that the influence of the Watercourses Convention is set to dominate emerging developments in connection with the utilization, conservation, and management of the Nile River. 